\title{
Emerald Ash Borer (Agrilus planipennis) Density and Canopy Dieback in Three North American Ash Species
}

\author{
Andrea C. Anulewicz, Deborah G. McCullough, and David L. Cappaert
}

\begin{abstract}
Emerald ash borer (Agrilus planipennis Fairmaire) (Coleoptera: Buprestidae), a phloem-feeding insect native to Asia, was identified in 2002 as the cause of widespread ash (Fraxinus) mortality in southeast Michigan, U.S. and Windsor, Ontario, Canada. Little information about A. planipennis is available from its native range and it was not known whether this invasive pest would exhibit a preference for a particular North American ash species. We monitored A. planipennis density and canopy condition on green ash $(F$. pennsylvanica) and white ash $(F$. americana) street trees in four neighborhoods and on white and blue ash (F. quadrangulata) trees in two woodlots in southeast Michigan. Green ash street trees had significantly more canopy dieback and higher A. planipennis densities than white ash trees growing in the same neighborhood. Density increased by two- to fourfold in both species over a 3-year period. Canopy dieback increased linearly from 2002 to 2005 as A. planipennis density increased $\left(\mathrm{R}^{2}=0.70\right)$. In each of the woodlots, A. planipennis densities were significantly higher on white ash trees than blue ash trees. Woodpecker predation occurred in all sites and accounted for $35 \%$ of the A. planipennis that developed on trees we surveyed. Results indicate that surveys for $A$. planipennis detection in areas with multiple ash species should focus on the relatively preferred species.

Key Words. Blue ash; emerald ash borer; Fraxinus; green ash; host preference; insect survey; invasive pest; white ash; woodpecker.
\end{abstract}

The emerald ash borer (Agrilus planipennis Fairmaire), an invasive buprestid, was identified in July 2002 as the cause of widespread ash (Fraxinus) mortality in southeast Michigan, U.S. and Windsor, Ontario, Canada (Cappaert et al. 2005c). Dozens of additional infestations have been found since 2003 in other areas of Michigan, Ohio, Indiana, Illinois, and Maryland (www.emeraldashborer.info 2006). Agrilus planipennis is native to China, Korea, and other Asian countries (Yu 1992) but is not a major pest in its native range (Akiyama and Ohmomo 2000). It was likely introduced into North America through solid wood packing material (Cappaert et al. 2005c; Poland and McCullough 2006).

In southeast Michigan, A. planipennis adult emergence begins in mid to late May (Brown-Rytlewski and Wilson 2005; Cappaert et al. 2005c). On emergence, beetles feed on ash foliage for 5 to 7 days before mating and another 5 to 7 days before females begin oviposition (Bauer et al. 2004; Lyons et al. 2004). Individual adult beetles live for 3 to 6 weeks and adult activity peaks from late June to early July (Cappaert et al. 2005c). Eggs laid in July and August hatch in $\approx 2$ weeks (Lyons et al. 2004). Larvae feed on phloem for several weeks, often scoring the outer sapwood (McCullough and Katovich 2004; www.emeraldashborer.info 2006). Most A. planipennis overwinter as prepupal larvae in shallow chambers excavated in the outer sapwood or in the bark of thick-barked trees. Recent evidence has shown that some larvae overwinter as early instars and complete their feeding during the second summer. The underlying cause of this extended development is not understood, but it seems to be most common in healthy trees with low densities of A. planipennis (Cappaert et al. 2005c). Woodpecker predation of prepupal larvae is common in many sites and occurs mostly during winter and early spring (Cappaert et al. 2005b; Lindell et al., unpublished data). Pupation begins in late April or May and adults emerge roughly 2 weeks later, leaving distinctive D-shaped exit holes, 3 to $4 \mathrm{~mm}$ ( 0.12 to $0.16 \mathrm{in}$ ) in diameter (McCullough and Katovich 2004).

In North America, A. planipennis is aggressively attacking healthy, as well as stressed, ash trees. An estimated 20 million ash trees in southeast Michigan alone were dead or dying by late 2006. This invasive pest could potentially spread throughout North America through natural dispersal by adult beetles and artificial spread caused by humans moving infested ash material. In the United States, there are at least 16 native species of Fraxinus (Harlow et al. 1991) and more than 8 billion ash trees on forest land (FIA 2006). At least 800 million ash trees occur on timberlands in Michigan, including green ash ( $F$. pennsylvanica), white ash ( $F$. americana), black 
ash ( $F$. nigra), and blue ash ( $F$. quadrangulata) (Barnes and Wagner 1981; FIA 2006). In natural forests, A. planipennis could substantially alter biodiversity and stand dynamics (MacFarland and Meyer 2005). Ash trees, particularly green ash and white ash, are also commonly planted in many urban areas of the United States (Ottman and Kielbaso 1976; Giedraitis and Kielbaso 1982; Poland and McCullough 2006).

Given the extensive damage that A. planipennis has caused to date, an important question is whether A. planipennis preferentially feeds or oviposits on certain North American species of Fraxinus. Understanding the preference hierarchy and underlying mechanisms of $A$. planipennis attraction among Fraxinus species will increase our ability to accurately assess stand susceptibility to this pest based on species composition. It is also important for developing survey, detection, and management options and predicting spread and impact of A. planipennis throughout North America.

To assess host preference, we quantified the density of A. planipennis exit holes and woodpecker attacks at four sites with green and white ash street trees and at two woodlots where white and blue ash trees co-occurred. We also monitored canopy dieback and changes in exit hole and woodpecker attack densities over time.

\section{MATERIALS AND METHODS}

\section{Study Sites}

Study sites were selected based on four criteria. Each site had to have two species of similarly sized ash trees that were untreated, growing in close proximity under similar site conditions, and presumably exposed to similar levels of A. planipennis pressure. Permission to survey trees was acquired from the respective property owners. Trees included in our surveys ranged from 4 to $38 \mathrm{~cm}$ (1.6 to $15.2 \mathrm{in}$ ) in diameter at breast height (dbh) (Table 1).

\section{Green versus White Ash Street Trees}

In 2003, we sampled green and white ash street trees at two sites (Table 1). At the first site, Butzel School in Detroit, Wayne County, Michigan, eight small green ash and eight small white ash trees were growing around the perimeter of the school yard. At the second site on Larned Boulevard, also in Detroit, there were 11 green ash trees on the east side of the street and 11 white ash trees in the grassy median (Table 1). In 2004, we also surveyed seven green ash and seven white ash trees growing in the grass strip between the sidewalk and the street in the Windemere neighborhood in Ann Arbor, Washtenaw County, Michigan (Table 1). The fourth site, surveyed during the 2005 season only, included eight green ash and nine white ash trees growing within $30 \mathrm{~m}(99 \mathrm{ft})$ of one another near the Lakeside Terraces condominium complex in Sterling Heights, Macomb County, Michigan (Table 1).

\section{White versus Blue Ash Woodlot Trees}

In 2004, we located two woodlots that had established $A$. planipennis populations and included white and blue ash trees growing in close proximity. In Superior Township, Washtenaw County, Michigan, white and blue ash trees ranged from 17 to $32 \mathrm{~cm}$ (6.8 to $12.8 \mathrm{in}$ ) in dbh and trees were growing 6 to $24 \mathrm{~m}$ (19.8 to $79.2 \mathrm{ft}$ ) apart (Table 1). In a woodlot in Plymouth Township, Wayne County, Michigan, trees ranged from 11 to $35 \mathrm{~cm}$ (4.4 to $14 \mathrm{in}$ ) in dbh and trees were growing 3 to $7 \mathrm{~m}$ (909 to $23.1 \mathrm{ft}$ ) apart (Table 1). Trees in both woodlots were surveyed in 2004 and trees were evaluated in Superior Township, again in 2005.

\section{Sampling and Data Collection}

\section{Green versus White Ash Street Trees}

For each tree, visual estimates of canopy dieback were made annually in late summer, when damage from the current year larvae had become apparent. The cumulative number of

Table 1. Number of trees $(n)$ and mean $( \pm$ SE) diameter at breast height (dbh) for green and white ash trees at four residential sites and blue and white ash trees at two woodlots.

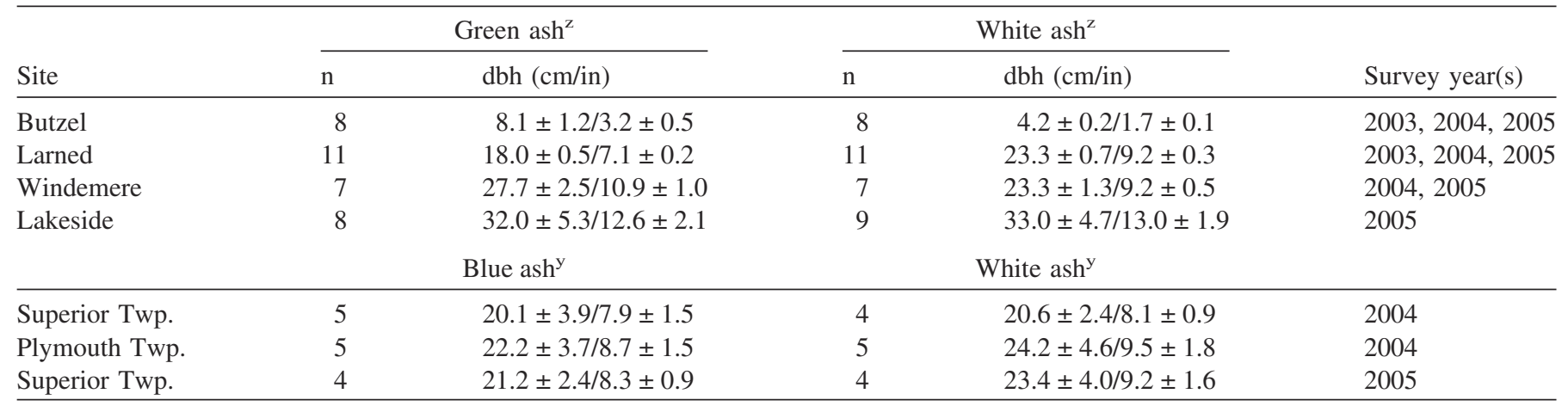

${ }^{\mathrm{z}}$ The same trees were resurveyed each year.

${ }^{\mathrm{y}}$ Trees were felled for sampling and new trees were selected each year. 
D-shaped exit holes made by emerging A. planipennis adults and woodpecker attacks were counted in the fall, after adult beetle emergence was complete. Woodpeckers primarily prey on prepupae, which have completed their feeding and would otherwise have a high probability of emerging as adults (Cappaert et al. 2005b, 2005c; Lindell et al. unpublished data). The sum of adult exit holes and woodpecker attacks, therefore, represented the cumulative number of A. planipennis larvae that developed in the area surveyed on each tree.

Exit holes and woodpecker attacks were counted on the entire trunk or branch circumference in four areas of each tree: at 1.5 and $3 \mathrm{~m}(4.95$ and $9.9 \mathrm{ft})$ aboveground, at the base of the lowest first order branch, and $1 \mathrm{~m}(3.3 \mathrm{ft})$ out on that branch. Areas above $1.5 \mathrm{~m}(4.95 \mathrm{ft})$ were accessed using a ladder. On each tree, an area of $\approx 0.26 \mathrm{~m}^{2}\left(\approx 2.81 \mathrm{ft}^{2}\right)$ was inspected at $1.5 \mathrm{~m}(4.95 \mathrm{ft})$ aboveground and $0.13 \mathrm{~m}^{2}$ $\left(1.40 \mathrm{ft}^{2}\right)$ was examined on the other three sample areas \{average total area of $0.65( \pm 0.01$ standard error [SE] $) \mathrm{m}^{2}$ $\left[7.0\left( \pm 0.11 \mathrm{SE} \mathrm{ft}{ }^{2}\right)\right.$ per tree] $\}$. At the Butzel site, 11 trees were less than $5 \mathrm{~cm}$ ( 2 in) in dbh, so the entire stem and all branches of each tree were examined. On average, we inspected $0.52\left\{( \pm 0.03 \mathrm{SE}) \mathrm{m}^{2}\left[5.60( \pm 0.32 \mathrm{SE}) \mathrm{ft}^{2}\right]\right\}$ on each of the small trees. Percentage of the canopy that was dead, number of A. planipennis exit holes, and number of woodpecker attacks on A. planipennis prepupal larvae was recorded for each area inspected on each tree. Mean A. planipennis density per tree was calculated by summing the total number of A. planipennis exit holes and woodpecker attacks and dividing by the total area sampled in the tree. In 2003, canopy dieback was recorded on 12 August and A. planipennis exit holes and woodpecker attacks were counted between 12 August and 11 October.

Survey methods were modified in 2004 because related research showed that initial attacks by A. planipennis were more common in the upper canopy than on the trunk (Cappaert et al. 2005a). Therefore, on all trees greater than $5 \mathrm{~cm}$ ( 2 in) in dbh, tree climbers inspected four to six areas between 1.5 and $8.5 \mathrm{~m} \mathrm{(4.95}$ and $28.1 \mathrm{ft}$ ) aboveground on each tree. On average, the total area examined on each tree was $1.04( \pm 0.07 \mathrm{SE}) \mathrm{m}^{2}\left[11.19( \pm 0.75 \mathrm{SE}) \mathrm{ft}^{2}\right]$. Small trees [dbh $<5 \mathrm{~cm}$ (2 in)] were completely surveyed as before. With the

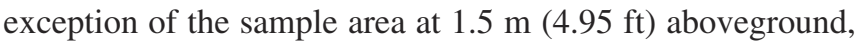
sample areas were randomly selected each year and may or may not have overlapped with areas sampled the previous year. Counts of exit holes and woodpecker attacks in 2004 were collected on 6 August at Butzel and Larned and on 9 August at Windemere. Canopy dieback was estimated at the three sites on 13 September. In July 2004, however, four green ash trees at Larned and two green ash and one white ash tree at Butzel were felled and removed from the survey sites by the respective municipalities. Canopy dieback for these seven trees was recorded as $100 \%$ in the subsequent year's survey.
Seven additional dead trees were removed in 2005, including one green ash and two white ash trees at Butzel and two green ash and two white ash trees at Windemere. The two white ash trees at Windemere were felled after dieback estimates were made but before exit hole and woodpecker attack data could be collected. Dieback for these five trees, therefore, was recorded as $100 \%$ in 2005. Dieback estimates were made on 16 September 2005 at all sites, except Lakeside where leaves began falling before estimates of dieback could be made. Exit holes and woodpecker attacks on the remaining 25 green ash and 30 white ash (55 trees total) were counted on 12 October at Butzel and Windemere, 19 October at Lakeside, and 19 and 21 October 2005 at Larned. Data collected from 25 green ash and 26 white ash trees (51 trees total) at Larned and Butzel in 2003 and at Windemere in 2004 were used to assess the relationship between canopy dieback and A. planipennis density.

\section{White versus Blue Ash Woodlot Trees}

On 2 March 2004, two white ash and three blue ash trees were surveyed by climbers in the Superior Township woodlot. Seven to 11 areas on the main stem and branches between 1.5 and $15 \mathrm{~m} \mathrm{(4.95} \mathrm{and} 49.5 \mathrm{ft})$ aboveground were examined per tree and A. planipennis exit holes and woodpecker attacks were recorded for each area. An average of $2.9( \pm 0.22 \mathrm{SE}) \mathrm{m}^{2}$ $\left[31.2( \pm 2.37 \mathrm{SE}) \mathrm{ft}^{2}\right]$ per tree was inspected. On 28 May 2004, before the onset of A. planipennis adult emergence, two additional white ash and two blue ash trees were felled. Four to eight intervals between 1.5 and $15 \mathrm{~m}(4.95$ and $49.5 \mathrm{ft})$ aboveground were inspected on each tree. An average of 0.8 $( \pm 0.09 \mathrm{SE}) \mathrm{m}^{2}\left[8.6( \pm 0.97 \mathrm{SE}) \mathrm{ft}^{2}\right]$ per tree was examined. Trees that were felled were debarked and the percentage of phloem surface area covered by A. planipennis galleries was estimated. The total number of exit holes and woodpecker attacks were summed and divided by the total area sampled for each tree. There was no significant difference between counts of A. planipennis density recorded by tree climbers and counts recorded after trees were felled $(S=26.0$; $\mathrm{df}=1,7 ; P=0.09)$. Because of the difficulty of accurately estimating dieback on tall, closed-canopy woodlot trees, dieback was not estimated for the woodlot trees.

On 20 January 2005, we felled five white ash and five blue ash trees in the Plymouth Township woodlot. Five to 16 trunk and branch sections between 1.5 and $17 \mathrm{~m} \mathrm{(4.95} \mathrm{and} 56.1 \mathrm{ft}$ ) aboveground were removed from each tree and transported to the laboratory for inspection and debarking. Average area sampled per tree was $1.4( \pm 0.21 \mathrm{SE}) \mathrm{m}^{2}\left[15.1( \pm 2.26 \mathrm{SE}) \mathrm{ft}^{2}\right]$. Number of A. planipennis exit holes, woodpecker attacks, and percentage of phloem surface area covered by galleries was recorded.

On 21 November and 2 December 2005, another four white ash and four blue ash trees in the Superior Township woodlot were felled and inspected using methods from the 
2004 Plymouth Township survey. Five to eight sections were taken from each tree between 1.5 and $21.5 \mathrm{~m}(4.95$ and $71 \mathrm{ft})$ aboveground with an average sample area of $1.1( \pm 0.10 \mathrm{SE})$ $\mathrm{m}^{2}\left[11.8( \pm 1.1 \mathrm{SE}) \mathrm{ft}^{2}\right]$ per tree.

\section{Statistical Analysis}

All data were tested for normality using the Shapiro-Wilk test (Shapiro and Wilk 1965) and residual plots. Data were not normally distributed after transformations. Therefore, the nonparametric Wilcoxon rank sum test (Ott and Longnecker 2001) was used to determine if the mean number of A. planipennis exit holes and woodpecker attack density, percentage of phloem surface area covered by galleries, and percentage of canopy dieback differed significantly between species at each site.

Counts of A. planipennis exit holes and woodpecker attacks and canopy dieback data from Larned and Butzel in 2003 and Windemere in 2004 were pooled and tested for normality. Data were normally distributed and simple linear regression was used to determine if canopy dieback was a significant predictor of A. planipennis exit hole and woodpecker attack densities. All analyses were conducted at the $P<0.05$ level of significance using SAS statistical software (SAS Institute 2003).

\section{RESULTS}

\section{Green versus White Ash Street Trees}

At the Butzel site where trees were small, canopy dieback of green ash trees was, on average, $13 \%$ to $20 \%$ higher than canopy dieback of white ash trees during the 3-year period, but differences were not significant in 2003 ( $\mathrm{S}=83.5$; $\mathrm{df}=1,14 ; P>0.0532), 2004(\mathrm{~S}=79.0 ; \mathrm{df}=1,14$ $P>0.13$ ), or 2005 ( $\mathrm{S}=73.0$; $\mathrm{df}=1,14 ; P>0.31$ ) (Figure 1A). Average canopy dieback for green ash and white ash trees increased $32 \%$ and $25 \%$, respectively, from 2003 to 2004, and $13 \%$ and $18 \%$, respectively, from 2004 to 2005 (Figure 1A). In 2004, canopy dieback, excluding the three dead green ash and one dead white ash trees that were removed, averaged $43 \%( \pm 10.2 \mathrm{SE})$ for green ash and $30 \%$ $( \pm 18.2 \mathrm{SE})$ for white ash. In 2005, canopy dieback (excluding the dead trees) averaged 53\% ( $\pm 11.4 \mathrm{SE})$ for green ash and $29 \%( \pm 18.5 \mathrm{SE})$ for white ash.

Green ash trees at Butzel had an average of 17 to 39 more exit holes and woodpecker attacks per $\mathrm{m}^{2}$ ( 2 to 4 per $\mathrm{ft}^{2}$ ) than white ash trees throughout the study, but differences were not significant in $2003(\mathrm{~S}=80.0 ; \mathrm{df}=1,14 ; P>0.11), 2004$ $(\mathrm{S}=47.0 ; \mathrm{df}=1,11 ; P>0.27)$, or $2005(\mathrm{~S}=33.0$; $\mathrm{df}=1,8 ; P>0.15$ ) (Figure 1B). Exit hole and woodpecker attack densities in green ash more than tripled from 2003 to 2004 and increased fivefold in white ash (Figure 1B). Densities remained relatively consistent from 2004 to 2005 (Figure 1B). Average exit hole density ranged from 21 to 78 exit

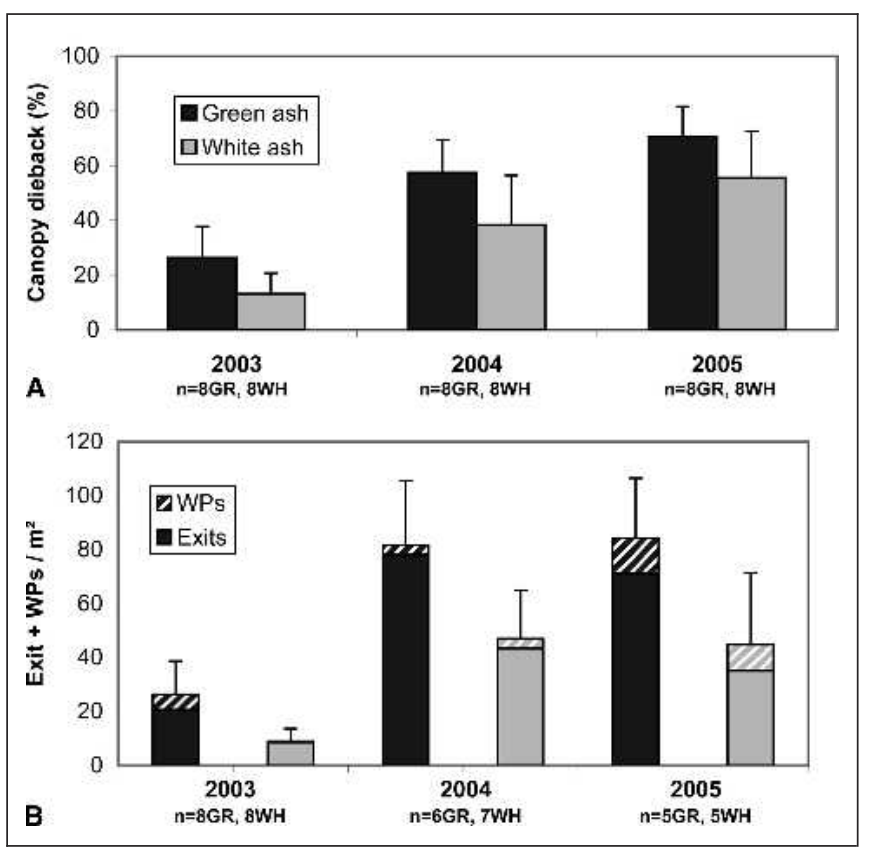

Figure 1. (A) Mean $( \pm S E$ ) percent canopy dieback and (B) mean $( \pm \mathrm{SE})$ number of Agrilus planipennis exits holes (exits) and woodpecker attacks (WPs) per meter squared for the small green (GR) and white (WH) ash trees at Butzel in 2003, 2004, and 2005. Three dead green ash and three dead white ash trees were removed in 2004 and 2005. Means for canopy dieback include removed trees as having $100 \%$ dieback. Means within years were not significantly different between species (Wilcoxon rank sum test; $P>0.05$ ).

holes $/ \mathrm{m}^{2}$ ( 2 to 7 per $\mathrm{ft}^{2}$ ) in green ash and 9 to 43 exit holes $/ \mathrm{m}^{2}$ ( 1 to 4 per $\mathrm{ft}^{2}$ ) in white ash from 2003 to 2005 . Woodpecker attacks were found on both branches and trunks of green and white ash trees. Average woodpecker attack density ranged from 4 to 13 woodpecker attacks $/ \mathrm{m}^{2}$ (0.3 to 1.2 per $\mathrm{ft}^{2}$ ) in green ash and 0 to 10 ( 0 to 1 per $\left.\mathrm{ft}^{2}\right)$ in white ash over the 3 -year period. On average, by 2005 , woodpeckers had preyed on $21 \%$ of the A. planipennis in these trees.

At Larned, green ash trees had significantly more canopy dieback than white ash trees in $2003(\mathrm{~S}=182.0$; $\mathrm{df}=1,20$; $P<0.0001), 2004$ (S = 187.0; df $=1,20 ; P<0.0001)$, and $2005(\mathrm{~S}=181.5 ; \mathrm{df}=1,20 ; P<0.0001)$ (Figure 2A). Dieback increased approximately $25 \%$ each year for both species and green ash trees averaged $49 \%$ to $69 \%$ more dieback than white ash trees (Figure 2A). In 2004, canopy dieback was $100 \%$ on six of the seven remaining green ash trees and only $10 \%$ of the canopy was alive on the other tree. By 2005 , all green ash trees in the survey were dead.

Green ash trees at Larned had 1.5 to four times as many A. planipennis exit holes and woodpecker attacks per $\mathrm{m}^{2}$ as white ash trees throughout the study. Exit hole and woodpecker attack densities were significantly greater in green ash 


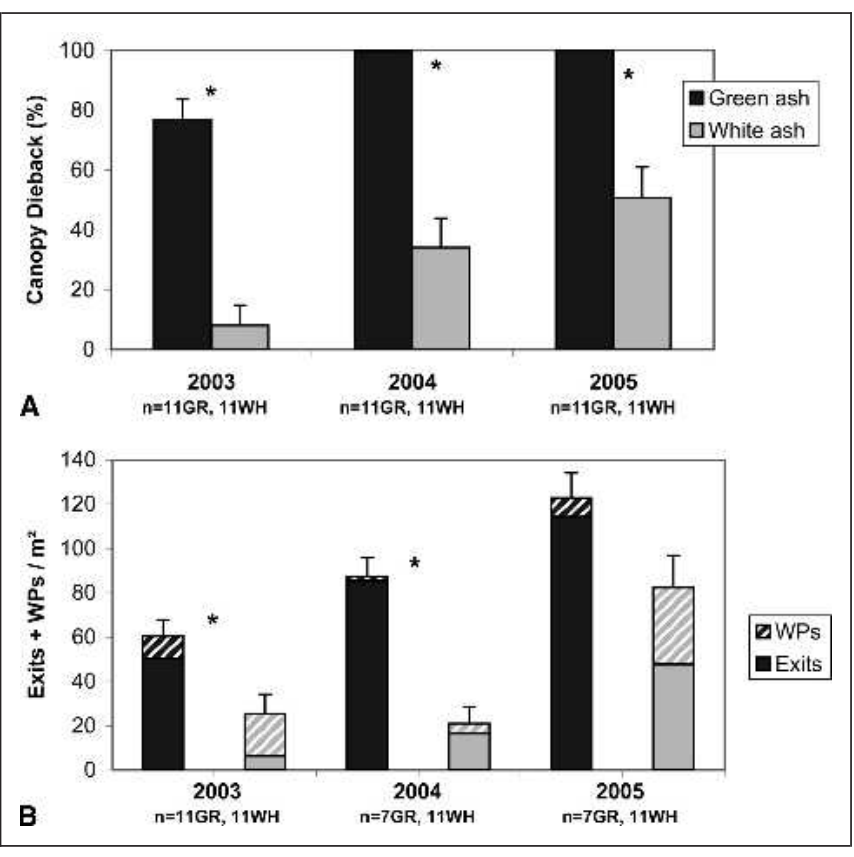

Figure 2. (A) Mean ( \pm SE) percent canopy dieback and (B) mean ( $\pm \mathrm{SE}$ ) number of Agrilus planipennis exits holes (exits) and woodpecker attacks (WPs) per meter squared for green (GR) and white (WH) ash trees at Larned in 2003, 2004, and 2005. Four dead green ash trees were removed in 2004. Means for canopy dieback include removed trees as having $100 \%$ dieback. ${ }^{*}$ Significant differences between green and white ash trees (Wilcoxon rank sum test; $P<0.05$ ).

than in white ash in 2003 and 2004 ( $\mathrm{S}=169.0$; df = 1,20; $P=0.002$ and $\mathrm{S}=101.0 ; \mathrm{df}=1,16 ; P<0.0004$, respectively), but differences were marginally insignificant in 2005 $(\mathrm{S}=85.0 ; \mathrm{df}=1,16 ; P=0.0521$ ) (Figure 2B). Exit hole and woodpecker attack densities in green ash increased by $45 \%$ from 2003 to 2004 and by $41 \%$ from 2004 to 2005 . Densities in white ash did not change dramatically from 2003 to 2004, but nearly quadrupled from 2004 to 2005 (Figure 2B). Average exit hole density ranged from 50 to 114 exit holes $/ \mathrm{m}^{2}$ ( 5 to 11 per $\mathrm{ft}^{2}$ ) in green ash and 6 to 48 exits holes $/ \mathrm{m}^{2}$ (0.5 to 4.5 per $\left.\mathrm{ft}^{2}\right)$ in white ash from 2003 to 2005 . Average woodpecker attack density ranged from 2 to 10 woodpecker attacks $/ \mathrm{m}^{2}\left(0.2\right.$ to 1 per $\left.\mathrm{ft}^{2}\right)$ in green ash and 4 to 35 woodpecks $/ \mathrm{m}^{2}$ (0.4 to 3 per $\mathrm{ft}^{2}$ ) in white ash. By 2005, all trees surveyed at the Larned site had woodpecks and, on average, woodpeckers preyed on $34 \%$ of the A. planipennis in these trees.

At Windemere, green ash trees had significantly more canopy dieback than white ash trees in both 2004 ( $\mathrm{S}=77.0$; $\mathrm{df}=1,12 ; P<0.0003)$ and $2005(\mathrm{~S}=77.0 ; \mathrm{df}=1,12$; $P<0.0003$ ) (Figure 3A). Green ash trees were at or near $100 \%$ dieback both years, whereas average dieback in white ash trees increased more than $45 \%$ from 2004 to 2005 . In
2005, two green ash trees were removed in midsummer and all of the five remaining green ash trees were dead by September.

In 2004, green ash trees at Windemere had significantly more A. planipennis exit holes and woodpecker attacks per $\mathrm{m}^{2}$ than white ash trees $(\mathrm{S}=66.0 ; \mathrm{df}=1,12 ; P=0.0487)$ (Figure 3B). In 2005, however, white ash trees had significantly greater exit hole and woodpecker densities than the remaining dead or dying green ash $(\mathrm{S}=17.0$; df $=1,8$; $P=0.0159)$. One white ash tree in 2005 with a recorded density of 229 exit holes and woodpecker attacks per meter squared (21 per $\mathrm{ft}^{2}$ ) was considered an outlier and removed from the data set. The data were reanalyzed and white ash trees still had significantly more exits holes and woodpecker attacks per meter squared than green ash trees $(\mathrm{S}=28.0$; df $=1,7 ; P=0.0317$ ) (Figure $3 \mathrm{~B}$ ). Average exit hole density from 2003 to 2005 ranged from 44 to 76 exit holes $/ \mathrm{m}^{2}$ (4 to 7 per $\mathrm{ft}^{2}$ ) on green ash and 32 to 93 exit holes $/ \mathrm{m}^{2}$ (3 to 9 per $\left.\mathrm{ft}^{2}\right)$ on white ash. Average woodpecker attack density ranged from 6 to 14 woodpecker attacks $/ \mathrm{m}^{2}\left(0.6\right.$ to 1.3 per $\left.\mathrm{ft}^{2}\right)$ on

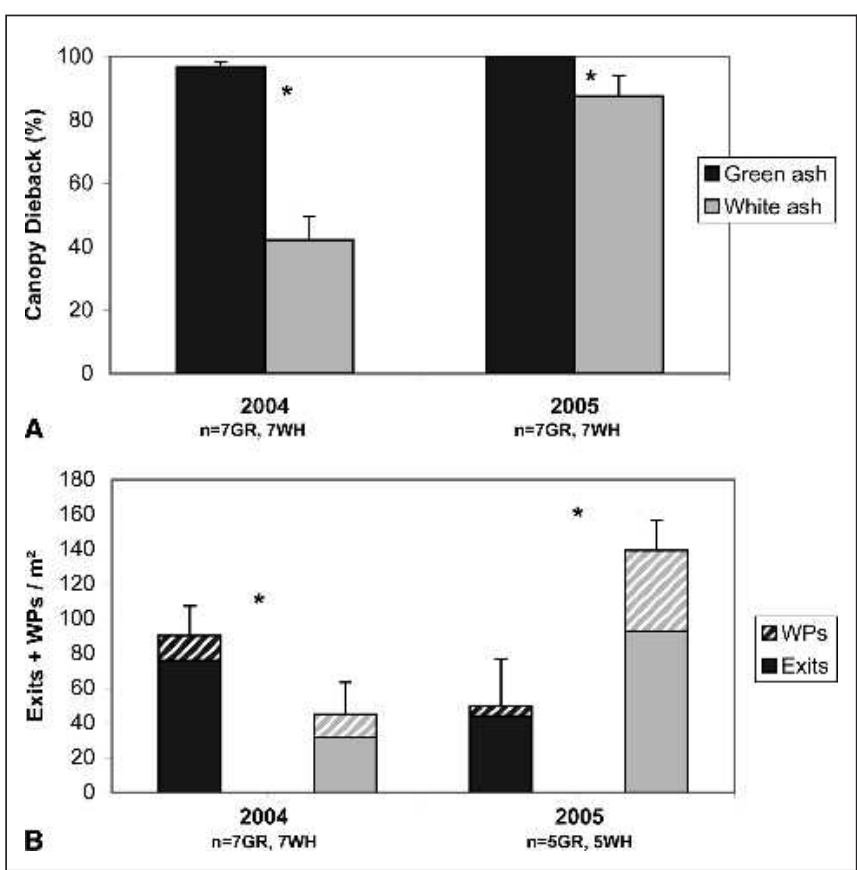

Figure 3. (A) Mean ( $\pm S E$ ) percent canopy dieback and (B) mean ( \pm SE) number of Agrilus planipennis exits holes (exits) and woodpecker attacks (WPs) per meter squared for green (GR) and white (WH) ash trees at Windemere in 2004 and 2005. Two dead green ash trees were removed in 2005. Means for canopy dieback include removed trees as having $100 \%$ dieback. One outlier for exits and woodpecks per meter squared was removed from the 2005 white ash tree data set. *Significant differences between green and white ash trees (Wilcoxon rank sum test; $P<0.05)$. 
green ash and 13 to 46 woodpecker attacks $/ \mathrm{m}^{2}(1.2$ to 4 per $\mathrm{ft}^{2}$ ) on white ash over the 3-year period. By 2005, all Windemere trees had woodpecker attacks and, on average, woodpeckers preyed on $27 \%$ of the A. planipennis in these trees.

Green ash trees at Lakeside, surveyed in 2005, had significantly more exit holes and woodpecks per meter squared than white ash trees with an average of $22.8( \pm 6.86 \mathrm{SE})$ per meter squared $\left[2.1( \pm 0.64 \mathrm{SE})\right.$ per $\left.\mathrm{ft}^{2}\right]$ for green ash and $5.9( \pm 1.02$ $\mathrm{SE})$ per meter squared $\left[0.6( \pm 0.09 \mathrm{SE})\right.$ per $\left.\mathrm{ft}^{2}\right]$ for white ash ( $\mathrm{S}=94.0 ; \mathrm{df}=1,15 ; P=0.0180)$. On green ash trees, $56 \%$ of the average total density was comprised of exit holes, whereas woodpeckers attacked the remaining $44 \%$ of the $A$. planipennis. On white ash trees, exit holes made up $29 \%$ of the average total density and woodpecker attacks made up $71 \%$ of A. planipennis density.

Overall, using the Butzel, Larned, and Windemere data, canopy dieback increased as the density of A. planipennis exit holes and woodpecker attacks increased. A positive and significant linear relationship existed between these two variables for green ash, for white ash, and the two species combined (Figure 4). In general, if dieback was less than $30 \%$, fewer than 30 exit holes and woodpecker attacks per meter squared $\left(3\right.$ per $\left.\mathrm{ft}^{2}\right)$ were found. If dieback was less than $50 \%$, the density of exit holes and woodpecker attacks ranged from 30 to 60 per $\mathrm{m}^{2}$ ( 3 to 6 per $\mathrm{ft}^{2}$ ) (Figure 4). Two dead trees had densities as low as 37 to 50 exit holes and woodpecker attacks per meter squared ( 3 to 5 per $\mathrm{ft}^{2}$ ). Overall, on trees with more than $90 \%$ dieback, the density of exit holes and woodpecker attacks ranged from 60 to 155 per $\mathrm{m}^{2}$ (6 to 14 per $\mathrm{ft}^{2}$ ) (Figure 4).

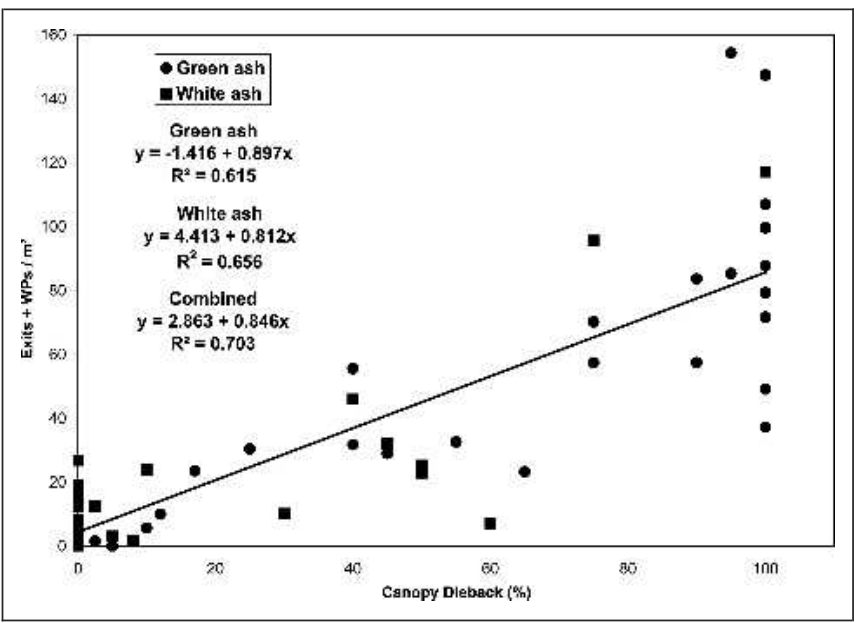

Figure 4. Percent canopy dieback and number of Agrilus planipennis exit holes (exits) and woodpecker attacks (WPs) per meter squared for 25 green ash and 24 white ash trees (49 trees total) surveyed at three residential sites in 2003 and 2004.

\section{White versus Blue Ash Woodlot Trees}

The white ash trees in both woodlots were heavily infested and declining or dying, whereas blue ash trees of similar size had much lower exit hole and woodpecker attack densities. In 2004, white ash trees in the Plymouth Township woodlot had significantly more A. planipennis exit holes and woodpecker attacks per meter squared than blue ash trees with an average of $80.1( \pm 20.65 \mathrm{SE})$ per $\mathrm{m}^{2}\left[7.4( \pm 1.92 \mathrm{SE})\right.$ per $\left.\mathrm{ft}^{2}\right]$ for white ash and $11.5( \pm 7.83 \mathrm{SE})$ per $\mathrm{m}^{2}\left[1.1( \pm 0.73 \mathrm{SE})\right.$ per $\left.\mathrm{ft}^{2}\right]$ for blue ash $(\mathrm{S}=16.0$; df $=1,8 ; P=0.0079)$. Exit holes and woodpecker attacks were found on branches and trunks of both species. Exit holes comprised $70 \%$ and $61 \%$ of the average total $A$. planipennis density in white ash and blue ash trees, respectively, whereas woodpecker attacks accounted for $30 \%$ and $39 \%$ of the A. planipennis in white and blue ash, respectively. Percentage of phloem surface area covered by A. planipennis larval galleries ranged from $0 \%$ to $100 \%$ in white ash, with an average of $39 \%( \pm 10.9 \mathrm{SE})$, and from $0 \%$ to $40 \%$ in blue ash, with an average of $8 \%( \pm 5.7 \mathrm{SE})$. Significantly more phloem area was covered by galleries in white ash than in blue ash $(\mathrm{S}=18.0$; df $=1,8$; $P=0.0278)$.

Similarly, in the Superior Township woodlot, white ash trees had significantly more exit holes and woodpecker attacks per meter squared than blue ash in 2004 ( $\mathrm{S}=30.0$; $\mathrm{df}=1,7 ; P=0.0079)$ and $2005(\mathrm{~S}=10 ; \mathrm{df}=1,6 ; P=$ 0.0143 ) (Figure 5). There was a significant increase in the density of exit holes and woodpecker attacks from 2004 to 2005 for the white ash trees in the Superior Township woodlot $(\mathrm{S}=26.0 ; \mathrm{df}=1,6 ; P=0.0143)$, but not for the blue

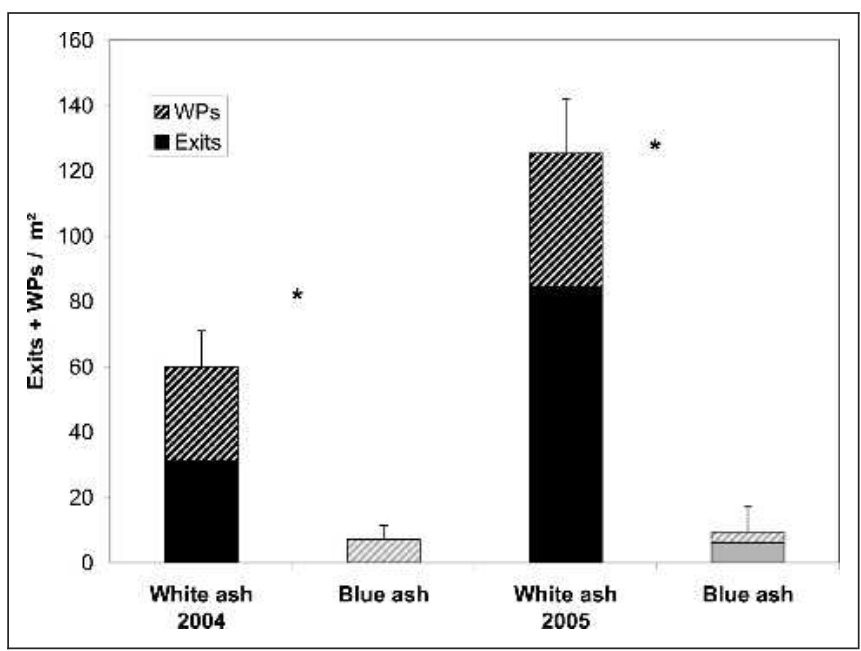

Figure 5. Mean ( \pm SE) number of Agrilus planipennis exit holes (exits) and woodpecker attacks (WPs) per meter squared for white and blue ash trees at Superior Township in 2004 and 2005. *Significant differences between white and blue ash trees (Wilcoxon rank sum test; $P<0.05$ ). 
ash trees $(\mathrm{S}=22.0 ; \mathrm{df}=1,7 ; P>0.36$ ) (Figure 5). For the two trees of each species that were felled and debarked in 2004, the percentage of phloem surface area covered by galleries ranged from $25 \%$ to $100 \%$ in white ash, with an average of $67 \%( \pm 5.9 \mathrm{SE})$, and from $0 \%$ to $40 \%$ in blue ash, with an average of $15 \%( \pm 7.6 \mathrm{SE})$. In 2005 , percentage of phloem covered by galleries ranged from $0 \%$ to $100 \%$ in white ash, with an average of $73 \%( \pm 8.1 \mathrm{SE})$, and from $0 \%$ to $30 \%$ in blue ash, with an average of $7 \%$ ( $\pm 5.0 \mathrm{SE})$. The percentage of phloem covered by galleries did not differ significantly between species in 2004 ( $\mathrm{S}=7.0 ; \mathrm{df}=1,2 ; P>0.17$ ), but were significant in 2005 ( $\mathrm{S}=10.0 ; \mathrm{df}=1,6 ; P=0.0143)$. Callous tissue grew around the edge of many of the galleries on blue ash trees, but we observed little evidence of callous tissue on white ash trees.

The overall frequency and extent of woodpecker predation was notable; more than $86 \%$ of the green, white, and blue ash trees included in our surveys had at least one woodpecker attack. The percentage of A planipennis killed by woodpeckers on urban street trees ranged from $0 \%$ to $100 \%$, with an average of $33 \%( \pm 5.8 \mathrm{SE})$. This predation rate was greater for woodlot trees, where woodpecker attacks killed $0 \%$ to $100 \%$ of the A. planipennis, with an average mortality of $48 \%( \pm 6.6 \mathrm{SE})$.

\section{DISCUSSION}

One of the key questions our study addressed was whether A. planipennis exhibits a host preference hierarchy among the predominant ash species native to Michigan. We determined that A. planipennis densities were consistently higher in green ash trees than in white ash trees growing in the same residential sites. Our counts represented the cumulative density of larvae that successfully completed their feeding and either emerged as adults or were preyed on by woodpeckers as prepupae. Our data also illustrate the progression of the A. planipennis infestation in sites monitored for multiple years. In the residential sites, A. planipennis densities in white ash increased from year to year as available phloem in green ash declined.

The only exception to this trend was at Windemere in 2005, where, on average, white ash trees had significantly higher exit hole and woodpecker attack densities than green ash both before and after the removal of the outlier point. Unlike the other sites that had fairly equal numbers of each species in the surrounding area, Windemere was unique in that the street trees were predominantly white ash with an occasional green ash tree in the midst of white ash trees. Singer (1983) noted that insects may not use their most highly preferred host if they encounter another acceptable host first. The reduced density of exit holes and woodpecker attacks in the green ash from 2004 to 2005 at Windemere [40 exit holes and woodpecker attacks per meter squared $\left(4\right.$ per $\left.\left.\mathrm{ft}^{2}\right)\right]$ also reflected the removal of two dead green ash trees in 2005.
Average A. planipennis densities would have been substantially greater if the dead trees had been retained in our annual surveys. Similarly, A. planipennis densities in trees at the Larned site would likely have been higher in 2005 if four dead trees had not been removed in 2004. At the Butzel site, where most trees were less than $5 \mathrm{~cm}$ ( 2 in) dbh, average A. planipennis densities were consistently higher in green ash than white ash trees, but differences between species were not significant. Because the trees were small, only a limited amount of phloem was available for A. planipennis at this site, probably obscuring some interspecific differences.

Agrilus planipennis clearly preferred white ash trees over blue ash trees in both woodlots we surveyed. When our survey began in 2004, numerous white ash trees in the two woodlots were declining or had been killed by A. planipennis, whereas nearby blue ash trees were just becoming infested. Blue ash trees may have also been less suitable hosts for developing larvae. We noted that callous tissue often grew on the edges or over the top of larval galleries on blue ash trees but was rarely associated with galleries on white or green ash trees. It was also evident that most larvae would have taken 2 years to develop on the blue ash trees. Future studies are needed to address potential differences among ash species in their phloem chemistry, attraction to ovipositing beetles, and initial resistance to $A$. planipennis larval feeding.

Canopy dieback caused by A. planipennis was consistently more pronounced in green ash trees than white ash trees at all residential sites in all years. Similar patterns have been observed in other infested areas. For example, in a residential site in Washtenaw County, Michigan, dieback on green ash trees averaged $60 \%$ compared with less than $10 \%$ dieback for white ash trees of the same age (McCullough et al. 2005). As expected, we found an increasing proportion of the canopy died each year, because the density of A. planipennis larvae escalated and the proportion of intact phloem declined.

Although canopy dieback, an external symptom of infestation, is not necessarily a direct measure of larval density, we did find a significant correlation between canopy dieback and the density of A. planipennis exit holes and woodpecker attacks. Linear models derived to describe this relationship were nearly identical for green ash and white ash trees, indicating that in both species, a $10 \%$ increase in dieback was associated with eight or nine more A. planipennis per meter squared $\left(\approx 1\right.$ per $\left.\mathrm{ft}^{2}\right)$.

Ash trees and other ring-porous hardwoods are generally more vulnerable to injury caused by phloem-feeding insects or wilt diseases than diffuse-porous hardwoods or conifers (Haack and Benjamin 1982; Kozlowski and Pallardy 1997). In the 14 dead green ash and 19 dead white ash trees we sampled in the residential and woodlot sites, the maximum number of A. planipennis per meter squared that were able to develop on a single tree was $\approx 107( \pm 10.8 \mathrm{SE})$ per meter squared $\left[10( \pm 1.0 \mathrm{SE})\right.$ per $\left.\mathrm{ft}^{2}\right]$ for green ash and $109( \pm 10.6$ 
SE) per meter squared $\left[10( \pm 1.0 \mathrm{SE})\right.$ per $\left.\mathrm{ft}^{2}\right]$ for white ash. McCullough and Siegert (2007) sampled 71 green and white ash trees killed by A. planipennis and reported that, on average, roughly 89 to 105 A. planipennis could develop per meter squared ( 8 to 10 per $\mathrm{ft}^{2}$ ).

At least six trees we surveyed had more than $50 \%$ dieback but less than $40 \mathrm{~A}$. planipennis exits or woodpecker attacks per millimeter squared $\left(4\right.$ per $\left.\mathrm{ft}^{2}\right)$. Although not all surveyed trees were debarked, a similar pattern was observed in other sites. If tree trunks become heavily infested before phloem in the canopy is exhausted, trees will succumb at lower A. planipennis densities than might otherwise be expected (McCullough and Siegert 2007). We also observed a few trees with extensive dieback that had virtually no exit holes or woodpecker attacks. Once these trees were debarked, it was apparent that nearly $100 \%$ of the phloem had been consumed, but virtually all larvae died as second or third instars because of intraspecific competition. The negative y-intercept derived for our green ash model likely reflected trees that exhibited some canopy dieback but few or no A. planipennis exit holes or woodpecker attacks.

Smitley et al. (2006) reported a significant correlation $\left(\mathrm{R}^{2}=0.59\right)$ between canopy dieback and density of A. planipennis exit holes in a survey of ash trees growing near highway exits in southeast Michigan. They counted exit holes visible on the tree trunks but did not examine branches in the canopy, which are usually colonized by $A$. planipennis before the trunk becomes infested (Cappaert et al. 2005c). A scatterplot of their data suggests that they observed a lower density of exit holes relative to canopy dieback than we observed, probably because they did not attempt to assess A. planipennis emergence in the canopy. For example, Smitley et al. (2006) recorded almost no exit holes in trees with $30 \%$ or less dieback. In contrast, we found up to 30 exit holes and woodpecker attacks per meter squared $\left(3\right.$ per $\left.\mathrm{ft}^{2}\right)$ in trees with $30 \%$ or less dieback.

Woodpeckers can play an important role in regulating populations of phloem-feeding or wood-boring beetle larvae (Anderson 1944; Nash et al. 1951; Barter 1957; Akers and Nielsen 1990; Fayt et al. 2005) and appear to be an important natural enemy of A. planipennis in North America (Cappaert et al. 2005b; Fuester and Schaefer 2006; Marshall et al. 2006; Strazanac 2006). Woodpeckers are known to feed on native buprestids such as A. anxius (bronze birch borer) with predation rates reportedly ranging from very low to $50 \%$ of $A$. anxius larvae (Anderson 1944; Nash et al. 1951; Barter 1957; Akers and Nielsen 1990). Overall, woodpecker attacks accounted for an average of $35 \%$ of the A. planipennis in the trees we surveyed. Other native natural enemies of A. planipennis in Michigan appear to be much less effective. Bauer et al. (2006) reported less than $2 \%$ of larvae were infected with pathogenic fungi, and less than $1 \%$ of larvae and $0.5 \%$ of eggs were killed by parasitoids. Even in its native range in
China, less than $7 \%$ of A. planipennis larvae, on average, were killed by hymenopteran parasitoids (Liu et al. 2003). Woodpeckers were present at all of the sites we surveyed and attacks were noted on trees with relatively low, moderate, and high A. planipennis densities. At least three species of woodpeckers have been observed preying on A. planipennis in Michigan (Lindell et al. unpublished data), but little is known about their functional or numerical responses to this invasive pest. More research is warranted to address woodpecker behavior and habitat use and effects of woodpecker predation on A. planipennis dynamics.

The observational data reported here provide a framework for future studies that will be needed to identify mechanisms that underlie differential host preference by A. planipennis. There are clearly differences in host susceptibility or vulnerability between North American ash species and Asian ash species, which have a long coevolutionary history with $A$. planipennis. In an experimental plot established in southeast Michigan in 2003, for example, European and North American ash species sustained more A. planipennis attacks and higher mortality than Manchurian ash, a species native to Asia (Herms et al. 2005). Liu et al. (2003) reported that in the 1960s, when a plantation of North American white ash was established in China, an outbreak of A. planipennis erupted and all of the trees were killed.

Within North America, numerous factors are likely to affect $A$. planipennis host selection and should not be considered mutually exclusive. Several studies have shown that although A. planipennis is capable of attacking healthy trees in North America, it prefers trees stressed by girdling or other biotic or abiotic agents (McCullough et al. 2005, 2006; Poland et al. 2006). This is consistent with observations made by Liu et al. (2003) who noted that in its native range, A. planipennis appears to function as a secondary pest, typically attacking stressed trees. Agrilus species native to North America such as A. bilineatus and A. anxius exhibit an analogous pattern, similarly typically attacking only hosts that are severely stressed by drought, defoliation, disease or injury (Anderson et al. 1944; Ball and Simmons 1980; Cote and Allen 1980; Dunn et al. 1986; Muzika et al. 2000; Herms 2002).

In addition, native Agrilus species and A. planipennis demonstrate an ovipositional preference for rough-barked portions of trees (Barter 1957; Loerch and Cameron 1984; Anulewicz 2006). Many varieties of green ash have rough, flaky bark even as young trees, whereas most varieties of white ash produce relatively smooth bark until they reach maturity. Blue ash trees, however, were less preferred or less suitable hosts than either green or white ash despite their rough textured bark. Host selection by A. planipennis is also likely affected by secondary compounds in ash leaves, bark, or phloem encountered by beetles as they feed on foliage or search for oviposition sites (Haack and Slansky 1986). Poland et al. (2006) found that traps baited with a blend of 
volatiles isolated from ash leaves captured significantly more A. planipennis than traps with individual compounds. Similarly, Crook et al. (2006) reported that sesquiterpenes isolated from ash bark elicited consistently strong antennal responses from A. planipennis adults.

Results from this study can be used to more thoroughly assess the susceptibility of both urban and forest trees based on species composition and to increase efficiency in developing survey, detection, and management options. In areas where two or more ash species occur, newly established or low-density populations of A. planipennis are more likely to be detected by focusing survey efforts on the preferred ash species (i.e., green ash). Additional research to evaluate interactions between A. planipennis and ash species may also identify traits that could be augmented or propagated to enhance resistance of North American trees to this invasive pest.

Acknowledgments. We thank Elizabeth Grisham, Robert McDonald, Sarah Smith, and Christopher Pell from Michigan State University (MSU) for their invaluable assistance in the field. We also thank Dr. Therese Poland (USDA Forest Service) and Dr. Bert Cregg (MSU) for their advice and support. We appreciate the cooperation provided by Dan Kurkowski, City of Detroit; Paul Bairley and Kay Sicheneder, City of Ann Arbor; Jan and Michael David BenDor, and Cynthia Shake for providing trees for survey. Funding for this project was provided by the USDA Agricultural Research Service, USDA Forest Service, Northeastern Area Forest Health Protection, and MSU's Project GREEEN.

\section{LITERATURE CITED}

Akers, R.C., and D.G. Nielsen. 1990. Spatial emergence patterns of bronze birch borer, (Coleoptera: Buprestidae) from European white birch. Journal of Entomological Science 25:150-157.

Akiyama, K., and S. Ohmomo. 2000. The Buprestid Beetles of the World. Iconographic Series of Insects 4. GekkanMushi Co., Ltd. 341 pp.

Anderson, R.F. 1944. The relation between host condition and attacks by the bronzed birch borer. Journal of Economic Entomology 37:588-596.

Anulewicz, A.C., D.G. McCullough, and D.L. Cappaert. 2006. Emerald ash borer host range and preference studies, pp. 15-16. In Emerald Ash Borer Research and Technology Development Meeting, Pittsburgh, PA, 26-27 Sept. 2005. V. Mastro, R. Reardon, and G. Parra, Eds. Morgantown, WV, U.S. Department of Agriculture, Forest Service publication FHTET-2005-16.

Ball, J., and G. Simmons. 1980. The relationship between bronze birch borer and birch dieback. Journal of Arboriculture 6:309-314.

Barnes, B.V., and W.H. Wagner. 1981. Michigan Trees: A Guide to the Trees of Michigan and the Great Lakes Region. Ann Arbor, The University of Michigan Press.
Barter, G.W. 1957. Studies of the bronze birch borer, Agrilus anxius Gory, in New Brunswick. The Canadian Entomologist 89:12-36.

Bauer, L.S., R.A. Haack, D.L. Miller, T.R. Petrice, and H. Liu. 2004. Emerald ash borer life cycle, p. 8. In Emerald Ash Borer Research and Technology Development Meeting, Port Huron, MI, 30 Sept.-1 Oct. 2003. V. Mastro and R. Reardon, Eds. Morgantown, WV, U.S. Department of Agriculture, Forest Service publication FHTET2004-02.

Bauer, L.S., H. Liu, R. Gao, and T. Zhao. 2006. Egg and larval parasitoids of emerald ash borer from China: Potential for biological control in North America, pp. 48-49. In Emerald Ash Borer Research and Technology Development Meeting, Pittsburgh, PA, 26-27 Sept. 2005. V. Mastro, R. Reardon, and G. Parra, Eds. Morgantown, WV, U.S. Department of Agriculture, Forest Service publication FHTET-2005-16.

Brown-Rytlewski, D.E., and M.A. Wilson. 2005. Tracking the emergence of emerald ash borer adults, pp. 13-14. In Emerald Ash Borer Research and Technology Development Meeting, Romulus, MI, 5-6 Oct. 2004. V. Mastro and R. Reardon, Eds. Morgantown, WV, U.S. Department of Agriculture, Forest Service publication FHTET-200415.

Cappaert, D., D.G. McCullough, and T.M. Poland. 2005a. Emerald ash borer life cycle: A reassessment, pp. 19-20. In Emerald Ash Borer Research and Technology Development Meeting, Romulus, MI, 5-6 Oct. 2004. V. Mastro and R. Reardon, Eds. Morgantown, WV, U.S. Department of Agriculture, Forest Service publication FHTET-200415.

- 2005b. The upside of the emerald ash borer catastrophe: A feast for woodpeckers, pp. 69-70. In Emerald Ash Borer Research and Technology Development Meeting, Romulus, MI, 5-6 Oct. 2004. Mastro and Reardon, Eds. Morgantown, WV, U.S. Department of Agriculture, Forest Service publication FHTET-2004-15.

Cappaert, D., D.G. McCullough, T.M. Poland, and N.W. Siegert. 2005c. Emerald ash borer in North America: A research and regulatory challenge. American Entomologist 51:152-165.

Cote, W.A., and D.C. Allen. 1980. Biology of the two-lined chestnut borer, Agrilus bilineatus, in Pennsylvania and New York. Annals of the Entomological Society of America 73:409-413.

Crook, D.J., I. Fraser, J.A. Francese, and V.C. Mastro. 2006. Chemical ecology of the emerald ash borer Agrilus planipennis Fairmaire (Coleoptera: Buprestidae), in relation to tree volatiles, pp. 63-64. In Emerald Ash Borer Research and Technology Development Meeting, Pittsburgh, PA, 26-27 Sept. 2005. V. Mastro, R. Reardon, 
and G. Parra, Eds. Morgantown, WV, U.S. Department of Agriculture, Forest Service publication FHTET-2005-16.

Dunn, J.P., T.W. Kimmerer, and G.L. Nordin. 1986. Attraction of the two-lined chestnut borer, Agrilus bilineatus (Weber) (Coleoptera: Buprestidae) and associated borers to volatiles of stressed white oak. The Canadian Entomologist 118:503-509.

Fayt, P., M.M. Machmer, and C. Steeger. 2005. Regulation of spruce bark beetles by woodpeckers-A literature review. Forest Ecology and Management 206:1-14.

Fuester, R.W., and P.W. Schaefer. 2006. Research on parasitoids of buprestids in progress at the ARS Beneficial Insects Introduction Research Unit, pp. 53-55. In Emerald Ash Borer Research and Technology Development Meeting, Pittsburgh, PA, 26-27 Sept. 2005. V. Mastro, R. Reardon, and G. Parra, Eds. Morgantown, WV, U.S. Department of Agriculture, Forest Service publication FHTET-2005-16.

Giedraitis, J.P., and J.J. Kielbaso. 1982. Municipal Tree Management. Urban Data Service Reports 14(1). Washington, DC, International City Management Association.

Haack, R.A., and D.M. Benjamin. 1982. The biology and ecology of the twolined chestnut borer, Agrilus bilineatus (Coleoptera: Buprestidae), on oaks, Quercus spp., in Wisconsin. The Canadian Entomologist 114:385-396.

Haack, R.A., and F.S. Slansky. 1986. Nutritional ecology of wood-feeding Coleoptera, Lepidoptera, and Hymenoptera, pp. 449-485. In Nutritional Ecology of Insects, Mites, Spiders, and Related Invertebrates. Slansky, F., and Rodriquez, J.G., Eds. New York, John Wiley and Sons, Inc. $1032 \mathrm{pp}$.

Harlow, W.M., E.S. Harrar, J.W. Hardin, and F.M. White. 1991. Textbook of Dendrology, 8th ed. New York, McGraw-Hill. 534 pp.

Herms, D.A. 2002. Strategies for deployment of insect resistant ornamental plants. pp. 217-235. In Mechanisms and Deployment of Resistance in Trees to Insects. Wagner, M.R., Clancy, K.M., Lieutier, C.V. and Paine, T.D., Eds. Dordrecht, The Netherlands, Kluwer Academic Publishing.

Herms, D.A., E. Rebek, D. Smitley, P. Bonello, and D. Cipollini. 2005. Interspecific variation in ash resistance to emerald ash borer, p. 33. In Emerald Ash Borer Research and Technology Development Meeting, Pittsburgh, PA, 26-27 Sept. 2005. V. Mastro and R. Reardon, Eds. Morgantown, WV, U.S. Department of Agriculture, Forest Service publication FHTET-2005-16, Morgantown, WV.

Kozlowski, T.T., and S.G. Pallardy. 1997. Physiology of Woody Plants. New York, Academic Press.

Liu, H., L.S. Bauer, R. Gao, T. Zhao, T.R. Petrice, and R.A. Haack. 2003. Exploratory survey for the emerald ash borer, Agrilus planipennis (Coleoptera: Buprestidae), and its natural enemies in China. The Great Lakes Entomologist 36:191-204.

Loerch, C.R., and E.A. Cameron. 1984. Within-tree distribution and seasonality of immature stages of the bronze birch borer, Agrilus anxius (Coleoptera: Buprestidae). The Canadian Entomologist 116:147-152.

Lyons, D.B., G.C. Jones, and K. Wainin-Keizer. 2004. The biology and phenology of the emerald ash borer, Agrilus planipennis, p. 5. In Emerald Ash Borer Research and Technology Development Meeting, Port Huron, MI, 30 Sept. -1 Oct. 2003. V. Mastro and R. Reardon, Eds. Morgantown, WV, U.S. Department of Agriculture, Forest Service publication FHTET-2004-02.

MacFarland, D.W., and S.P. Meyer. 2005. Characteristics and distribution of potential ash tree hosts for emerald ash borer. Forest Ecology and Management 213:15-24.

Marshall, S.A., S.M. Paiero, M. Buck, and B.D. Gill. 2006. Using Cerceris fumipennis wasps to monitor the spread of emerald ash borer, p. 56. In Emerald Ash Borer Research and Technology Development Meeting, Pittsburgh, PA, 26-27 Sept. 2005. V. Mastro, R. Reardon, and G. Parra, Eds. Morgantown, WV, U.S. Department of Agriculture, Forest Service publication FHTET-2005-16.

McCullough, D.G., and S.A. Katovich. 2004. Emerald Ash Borer. Pest Alert. USDA Forest Service, State and Private Forestry, Northeastern Area, NA-PR-02-04.

McCullough, D.G., T.M. Poland, and D.L. Cappaert. 2006. Attraction of emerald ash borer to trap trees: Effects of stress agents and trap height, pp. 61-62. In Emerald Ash Borer Research and Technology Development Meeting, Pittsburgh, PA, 26-27 Sept. 2005. V. Mastro, R. Reardon, and G. Parra, Eds. Morgantown, WV, U.S. Department of Agriculture, Forest Service publication FHTET-2005-16.

McCullough, D.G., T.M. Poland, D. Cappaert, P. Lewis, and J. Molongowski. 2005. Evaluation of trunk injections for control of emerald ash borer, pp. 38-99. In Emerald Ash Borer Research and Technology Development Meeting, Romulus, MI, 5-6 Oct. 2004. V. Mastro and R. Reardon, Eds. Morgantown, WV, U.S. Department of Agriculture, Forest Service publication FHTET-2004-15.

McCullough, D.G., and N.W. Siegert. 2007. Estimating potential emerald ash borer (Agrilus planipennis Fairmaire) populations using ash inventory data. Journal of Economic Entomology (in press).

Muzika, R.M., A.M. Liebhold, and M.J. Twery. 2000. Dynamics of twolined chestnut borer Agrilus bilineatus as influenced by defoliation and selection thinning. Agricultural and Forest Entomology 2:283-289.

Nash, R.W., E.J. Duda, and N.H. Gray. 1951. Studies on the extensive drying, regeneration, and management of birch. Maine Forest Service Bulletin 15. 82 pp. 
Ott, R.L., and M. Longnecker. 2001. An Introduction to Statistical Methods and Data Analysis. Duxbury Thomson Learning, Inc.

Ottman, K.A., and J.J. Kielbaso. 1976. Managing Municipal Trees. Urban Data Service Reports 8(11). International City Management Association. Washington, DC, November $1976.15 \mathrm{pp}$.

Poland, T.M., and D.G. McCullough. 2006. Emerald ash borer: Invasion of the urban forest and the threat to North America's ash resource. Journal of Forestry 104:118-124.

Poland, T.M., C. Rodriguez-Saona, G. Grant, L. Buchan, P. de Groot, J. Miller, and D.G. McCullough. 2006. Trapping and detection of emerald ash borer: Identification of stress-induced volatiles and tests of attraction in the lab and field, pp. 64-65. In Emerald Ash Borer Research and Technology Development Meeting, Pittsburgh, PA, 26-27 Sept. 2005. V. Mastro, R. Reardon, and G. Parra, Eds. Morgantown, WV, U.S. Department of Agriculture, Forest Service publication FHTET-2005-16.

SAS Institute. 2003. PROC user's manual, version 9.1. Cary, NC, SAS Institute.

Shapiro, S.S., and M.B. Wilk. 1965. An analysis of variance test for normality. Biometrika 52:591-599.

Singer, M.C. 1983. Determinants of multiple host use by a phytophagous insect population. Evolution; International Journal of Organic Evolution 37:389-403.

Smitley, D., E. Rebek, and T. Davis. 2006. Ash dieback in Michigan, 2003-2005, pp. 68-69. In Emerald Ash Borer Research and Technology Development Meeting, Pittsburgh, PA, 26-27 Sept. 2005. V. Mastro, R. Reardon, and G. Parra, Eds. Morgantown, WV, U.S. Department of Agriculture, Forest Service publication FHTET-2005-16.

Strazanac, J.S. 2006. Overview of Hymenoptera genera currently considered for emerald ash borer biocontrol release, p. 51. In Emerald Ash Borer Research and Technology Development Meeting, Pittsburgh, PA, 26-27 Sept. 2005. V. Mastro, R. Reardon, and G. Parra, Eds. Morgantown, WV, U.S. Department of Agriculture, Forest Service publication FHTET-2005-16.

U.S. Department of Agriculture Forest Inventory and Analysis Database (FIA) 2006. (U.S. Department of Agriculture Forest Inventory and Analysis Database) http://fia.fs. fed.us (accessed 12/04/06).

www.emeraldashborer.info. 2006. Multi-state emerald ash borer web site, housed at Michigan State University. Accessed 26 January 2007.

Yu, C. 1992. Agrilus marcopoli Obenberger, pp. 400-401. In Forest Insects of China, 2nd ed. Xiao, G., Ed. Beijing, China, China Forestry Publishing House.

Andrea C. Anulewicz (corresponding author)

Departments. of Entomology and Forestry

Michigan State University

\author{
243 Natural Science \\ East Circle Drive \\ East Lansing, MI 48824, U.S. \\ andreaa@msu.edu
}

Deborah G. McCullough

Departments of Entomology and Forestry

Michigan State University

243 Natural Science

East Circle Drive

East Lansing, MI 48824, U.S.

David L. Cappaert

Department of Entomology

Michigan State University

243 Natural Science

East Circle Drive

East Lansing, MI 48824, U.S.

Résumé. L'agrile du frêne (Agrilus planipennis Fairmaire) (coléoptère de la famille des Buprestidacées), un insecte originaire d'Asie qui s'alimente du phloème, a été identifié en 2002 comme la cause de la mortalité à grande échelle du frêne dans le Sud-est du Michigan et la région de Windsor en Ontario. Peu d'informations sur A. planipennis est disponible quant à son milieu d'origine et on ne sait pas non plus si cet insecte invasif va démontrer une préférence pour une espèce particulière de frêne indigène de l'Amérique du Nord. Nous avons suivi la densité de A. planipennis ainsi que la condition du couvert arboré du frêne de Pennsylvanie (Fraxinus pennsylvanica) et du frêne d'Amérique ( $F$. americana) en arbres de rues au sein de quatre quartiers ainsi que du frêne d'Amérique et du frêne bleu ( $F$. quadrangulata) dans deux boisés du Sud-est du Michigan. Les frênes de Pennsylvanie de rues avaient une mortalité de cime significativement plus élevée ainsi que des densités en $A$. planipennis aussi plus élevées par rapport aux frênes d'Amérique dans les mêmes quartiers. La densité augmentait de 2 à 4 fois chez ces deux espèces après trois ans. La mortalité du couvert arboré augmentait de manière linéaire de 2002 à 2005 avec l'augmentation de la densité en $A$. planipennis $\left(\mathrm{R}^{2}=0,70\right)$. Dans chacun des boisés, les densités en A. planipennis étaient significativement plus élevées chez le frêne d'Amérique que le frêne bleu. La prédation par les pics était présente sur tous les sites et comptait pour $35 \%$ des arbres étudiés où $A$. planipennis s'était développé. Les résultats indiquent que les inventaires pour la détection de $A$. planipennis dans les zones où plusieurs espèces de frênes sont présentes devraient se faire en fonction des préférences de l'insecte.

Zusammenfassung. Der Eschenbohrer (Agrilus planipennis Fairmaire), ein aus Asien stammendes Insekt, welches Phloem frisst, wurde 2002 als die Ursache von einem weitverbreiteten Eschensterben in Südwest-Michigan und Windsor, Ontario identifiziert. Es ist wenig Information über den Bohrer und sein natürliches Wirtsspektrum erhältlich und es ist nicht bekannt, ob dieses Schadinsekt eine Vorliebe für bestimmte amerikanische Eschen hat. Wir beobachteten die Populationsdichte des Insekts und den Zustand der Belaubung von Grünen und Weißen Eschen als Straßenbäume in vier Gemein- 
den und auf Weißer und Blauer Esche an zwei Waldstandorten in Südost-Michigan. Die Grünen Eschen hatten wesentlich mehr Absterbeerscheinungen in der Krone und größere Schädlingspopulationen als die Weißen Eschen in der Nachbarschaft. Die Populationsstärke stieg um das zwei- bis vierfache bei beiden Arten in einer dreijährigen Periode. Das Kronenabsterben stieg linear von 2002 bis 2005, als die Populationen anstiegen $\left(\mathrm{R}^{2}=0,70\right)$. An den beiden Waldstandorten waren die Populationen auf den Weißen Eschen wesentlich höher als auf den Blauen Eschen. Spechte griffen an allen Standorten in das Geschehen ein und vertilgten $35 \%$ der beobachteten Schadinsekten. Die Ergebnisse zeigen, dass Untersuchungen zum Vorkommen von A. planipennis in Gegenden mit vielen Eschenarten sich auf die bevorzugten Eschen konzentrieren sollten.

Resumen. El barrenador esmeralda del fresno (Agrilus planipennis Fairmaire) (Coleoptera: Buprestidae), un insecto que se alimenta del floema, nativo de Asia, fue identificado en 2002 como la causa de la mortalidad del fresno (Fraxinus) en el sureste de Michigan y Windsor, Ontario. Hay poca información disponible acerca de $A$. planipennis en su rango nativo y no se conocía si esta plaga invasiva prefiriera una especie de fresno Norte americano en particular. Se monitoreó la condición de la copa y la densidad de A. planipennis en fresno verde $(F$. pennsylvanica) y fresno blanco $(F$. americana) en árboles de la calle en cuatro vecindarios y en fresno blanco y azul $(F$. quadrangulata) en dos lotes arbolados en el sureste de Michigan. Los árboles de fresno verde tuvieron significativamente más muerte regresiva de la copa y más alta densidad de A. planipennis que los fresnos blancos creciendo en el mismo vecindario. La densidad incrementó de 2 a 4 veces en ambas especies en un período de tres años. La muerte regresiva incrementó linealmente de 2002 a 2005 a medida que las densidad de A. planipennis incrementó $\left(\mathrm{R}^{2}=0.70\right)$. En cada uno de los lotes arbolados, las densidades de A. planipennis fueron significativamente más altas en fresnos blancos que en azules. La depredación del pájaro carpintero ocurrió en todos los sitios y contabilizó por 35\% de A. planipennis desarrollado en los árboles que sobrevivieron. Los resultados indican que las encuestas para la detección de A. planipennis en áreas con múltiples especies de fresno deberán enfocarse a especies preferidas, relativamente. 